\title{
Comparative analysis of iron deficiency chlorosis responses in soybean (Glycine max) and barrel medic (Medicago truncatula)
}

\section{Análise comparativa das respostas à clorose por insuficiência de ferro em soja (Glycine max) e luzerna-cortada (Medicago truncatula)}

\author{
Carla S. Santos*, Inês Serrão e Marta W. Vasconcelos \\ Universidade Católica Portuguesa, Escola Superior de Biotecnologia, CBQF - Centro de Biotecnologia e Química Fina - Laboratório Associado, Rua Arquiteto Lobão Vital, Apartado 2511, 4202- \\ 401 Porto, Portugal. \\ ( ${ }^{\star} E$-mail: cssantos@porto.ucp.pt) \\ http://dx.doi.org/10.19084/RCA16090
}

Received/recebido: 2016.07.13

Accepted/aceite: 2016.12.02

\begin{abstract}
A B S T R A C T
Legume grains have an important socio-economical role, being highly utilized in human and animal nutrition. Although iron (Fe) is abundant in the earth's crust, its limited solubility makes it poorly bioavailable for plants, contributing to iron deficiency chlorosis (IDC). In this work the physiological and molecular mechanisms associated with IDC were studied, namely, the mechanisms involved on Fe deficiency response, as well as a new Fe metabolism related gene in two important legume crops, Glycine max and Medicago truncatula. Fe deficient plants developed: decreased root and shoot length, increased number of secondary roots and lower chlorophyll levels. Fe shoot content decreased six- and 11-fold for G. max and $M$ truncatula in Fe-deficiency. Whilst in G. max roots no significant differences were detected, in M. truncatula roots Fe decreased nine-fold in Fe-deficiency. Genes involved in Fe uptake (FRO2-like and IRT1-like), were over-expressed in roots of Fe-sufficient G. max and in Fe-deficient M. truncatula. VIT1-like, YSL1-like and ferritin presented higher expression levels in Fe-sufficient shoots and roots, whereas NRAMP3-like and GCN2-like showed higher expression values in Fe-deficiency.
\end{abstract}

Key Words: Ferric reductase, Glycine max, Medicago truncatula, morphological analysis, RT-PCR.

\section{R E S U M O}

As leguminosas têm um importante papel socio-económico, pela sua utilização na nutrição humana e animal. Apesar do ferro (Fe) ser um elemento abundante na crosta terrestre, a sua solubilidade limitada diminui a disponibilidade para as plantas, contribuindo para o desenvolvimento da Clorose por Insuficiência de Ferro (CIF). No presente trabalho, mecanismos fisiológicos e moleculares associados à CIF foram estudados, nomeadamente, os mecanismos de resposta à insuficiência de Fe e um novo gene associado ao metabolismo do Fe, em duas espécies cultivadas com relevância económica, Glycine max e Medicago truncatula. Plantas deficientes em Fe apresentaram: tamanho diminuído, maior número de raízes secundárias e baixos níveis de clorofila. Em insuficiência de Fe, o conteúdo de Fe na parte aérea diminuiu seis e onze vezes para G. max e M. truncatula, respetivamente; nas raízes de G. max não houve diferenças significativas e nas de M. truncatula o conteúdo de Fe diminuiu nove vezes. Genes envolvidos na absorção de Fe (FRO2like e IRT1-like) foram sobre-expressos nas raízes de G. max em suficiência de Fe e, nas raízes de M. truncatula, quando em insuficiência. VIT1-like, YSL1-like e ferritina apresentaram níveis de expressão mais elevados em suficiência de Fe, ao contrário dos genes NRAMP3-like e GCN2-like, cuja expressão foi aumentada em insuficiência de Fe.

Palavras-chave: Análise morfológica, luzerna-cortada, reductase férrica, RT-PCR, soja. 


\section{INTRODUCTION}

Legumes represent one of the most important foods, for both humans and animals (Vasconcelos and Grusak, 2006), providing an important source of protein and oil (Libault et al., 2010). One of the world's top commodity production is soybean (Glycine max L.). In fact, much of the world's protein and oil comes from soybean and this legume contains more protein $(40 \%)$ and oil $(20 \%)$ than any other ordinary food source, including meat, cheese and fish (Krishnan, 2005; Bolon et al., 2010). The appropriate addition of soy to different products, results in lower calorie alternative food products, with high content of protein, dietary fiber and minerals, preserving the physical and sensory characteristics of the product (Dhingra and Jood, 2001). The genome of soybean was sequenced, assembled and published (Schmutz et al., 2010), making it a good model crop to study genetic and molecular mechanisms. Barrel medic (Medicago truncatula) has been chosen as a model species for molecular studies in view of its growth and genomic characteristics (Trieu et al., 2000). To be convenient as a model for legume genomics, it is also essential that $M$. truncatula exhibit genome conservation with other crop legumes. Detailed comparisons between $M$. truncatula and $M$. sativa - a high feeding value crop used in animal nutrition - have reported that marker relationships were uniformly syntonic and that genes from $M$. truncatula share very high sequence identity to their counterparts from $M$. sativa, so it serves as an excellent model organism for soybean and other economically important legumes (Bell et al., 2001; Choi et al., 2004).

Besides protein and oil, legumes are also an important source of micronutrients, such as iron (Fe) (Vasconcelos and Grusak, 2006). This mineral is involved in the production of chlorophyll, and is also a component of many enzymes associated with the antioxidant system, energy transfer and nitrogen reduction and fixation. Legumes are very susceptible to Fe deficiency, when grown in adverse conditions, like calcareous soils, due to the low solubility of the oxidized form of $\mathrm{Fe}\left(\mathrm{Fe}^{3+}\right)$ at near neutral and alkaline soil $\mathrm{pH}$ (Waters et al., 2002; Andaluz et al., 2009). Insufficient Fe uptake leads to Fe-deficiency chlorosis (IDC) symptoms, such as yellowing of the younger leaves, interveinal chlorosis and stunted growth, as well as reduction of crop yields (Prasad, 2003; Kim and Guerinot, 2007). IDC lowers the concentrations of Fe in the seeds and other harvested tissues (Grusak, 1999), affecting both farmer profit and the nutritional value of plant products (Vasconcelos and Grusak, 2013).

In order to uptake Fe from the soil, dicotyledonous plants such as soybean and barrel medic, utilize Strategy I, where $\mathrm{Fe}^{3+}$ is reduced to $\mathrm{Fe}^{2+}$ through the action of a membrane-bound $\mathrm{Fe}^{3+}$-chelate reductase, like the ferric reduction oxidase (FRO). $\mathrm{Fe}^{2+}$ is then transported into the plant by specific membrane transporters (Grotz and Guerinot, 2006), such as the Iron-Regulated Transporter 1 (IRT1) (Waters et al., 2002). A broad spectrum of transporters have been characterized, such as the Natural Resistance Associated Macrophage (NRAMP) proteins, involved in Fe import into the cytoplasm, the Vacuolar Iron Transporter (VIT), involved in the uptake of $\mathrm{Fe}^{2+}$ into the vacuole for storage (Brear et al., 2013), and the Yellow Stripe 1-Like (YSL), involved in the transport of $\mathrm{Fe}^{2+}$ NA complexes (Kim et al., 2006). Free Fe is toxic since it facilitates the generation of highly reactive oxygen species (ROS). ROS can damage cellular constituents and, therefore, Fe homeostasis needs to be strictly controlled to avoid iron deficiency and toxicity (Liao et al., 2012). Therefore, storage proteins, such as Ferritin, play an important role in iron homeostasis, since they assure that ferric Fe is bio-available in case of cellular needs but yet nonreactive with oxygen (Briat et al., 2010).

Even though much has been learned about the physiology of Fe uptake in Arabidopsis, there is still a limited understanding of the physiology of tolerance to Fe deficiency in soybean and barrel medic, and this has hampered breeding programs (Vasconcelos and Grusak, 2013). There have been few works focusing in the comparative study between these two species (Yan et al., 2004), however more information is needed to understand the mechanisms at a molecular level, such as which genes have been selectively conserved or lost between both species. Since increasing the Fe uptake in the roots can augment Fe concentrations in the leaves, it is possible that some of this additional Fe may be remobilized to the grains, which would help in biofortification efforts that aim at enhancing Fe seed levels (Santos et al., 2013, 
2015). However, the increased Fe translocation from shoots to seeds still remains one of the major bottlenecks in most biofortification programs (White and Broadley, 2005), and the answer to this may be in the identification of new candidate genes. GCN2 is a protein kinase present in several organisms such as mammals and yeasts (Lageix et al., 2008) and is activated in plants by amino acid deprivation conditions (Zhang et al., 2008), as well other stress stimuli, such as purine deprivation, UV light, cold shock and wounding (Lageix et al., 2008). To this date, there are no published studies on the role of GCN2 on Fe uptake in plants growing in Fe deficiency, which makes the study of this gene an important innovation in Fe nutrition in plants. However, its regulation is still not well known (Liu et al., 2015), which makes it relevant to study this gene, in order to understand how its expression is affected by Fe deficiency and which mechanisms it may be associated with.

The present study describes the common mechanisms underlying the response to $\mathrm{Fe}$ deficiency at a physiological and molecular level, in G. max and M. truncatula grown hydroponically under Fe deficiency and Fe sufficiency. It also describes further analysis on the role of a novel candidate gene, GCN2, on Fe metabolism.

\section{MATERIALS AND METHODS}

\section{Plant material and growth conditions}

Medicago truncatula cultivar Luzerna revilheira and Glycine max cultivar Williams 82 were grown in a growth chamber (Aralab Fitoclima 10000EHF) with 16 $\mathrm{h}$ day $/ 8 \mathrm{~h}$ night photoperiod. The temperature was kept at $20^{\circ} \mathrm{C}$ during the light period, with $350 \mu \mathrm{mol} \mathrm{s}^{-1} \mathrm{~m}^{-2}$ of photon flux density, and at $18{ }^{\circ} \mathrm{C}$ during the dark period, with $75 \%$ of relative humidity. Seeds of $M$. truncatula and of G. max were germinated for seven days in the dark and then transferred to hydroponic solutions with $20 \mu \mathrm{M}$ FeEDDHA $(\mathrm{Fe}+)$ or with no FeEDDHA (Fe-) supply. The standard solution for hydroponic growth of $M$. truncatula contained as macronutrients: $3 \mathrm{mM}$ $\mathrm{KNO}_{3}, 1 \mathrm{mM} \mathrm{Ca}\left(\mathrm{NO}_{3}\right)_{2}, 0.5 \mathrm{mM} \mathrm{MgSO}{ }_{4} .7 \mathrm{H}_{2} \mathrm{O}, 0.5$ $\mathrm{mM} \mathrm{NH} \mathrm{H}_{2} \mathrm{PO}_{4}, 0.75 \mathrm{mM} \mathrm{K} \mathrm{SO}_{4}, 25 \mu \mathrm{M} \mathrm{CaCl}_{2}$; and as micronutrients: $25 \mu \mathrm{M} \mathrm{H}_{3} \mathrm{BO}_{3}, 2 \mu \mathrm{M} \mathrm{MnSO}_{4}, 2 \mu \mathrm{M}$ $\mathrm{ZnSO}_{4} \cdot \mathrm{H}_{2} \mathrm{O}, 0.5 \mu \mathrm{M} \mathrm{CuSO}_{4} \cdot \mathrm{H}_{2} \mathrm{O}, 0.5 \mu \mathrm{M} \mathrm{MoO}_{3}, 0.5$ $\mu \mathrm{M} \mathrm{NiSO}{ }_{4}$. The conditions used for $G$. max included as macronutrients: $1.2 \mathrm{mM} \mathrm{KNO}_{3}, 0.8 \mathrm{mM} \mathrm{Ca}\left(\mathrm{NO}_{3}\right)_{2}, 0.3$ $\mathrm{mM} \mathrm{MgSO}{ }_{4} \cdot 7 \mathrm{H}_{2} \mathrm{O}, 0.2 \mathrm{mM} \mathrm{NH} \mathrm{H}_{4} \mathrm{H}_{2} \mathrm{PO}_{4}, 25 \mu \mathrm{M} \mathrm{CaCl}_{2}$; and as micronutrients: $25 \mu \mathrm{M} \mathrm{H}_{3} \mathrm{BO}_{3}, 0.5 \mu \mathrm{M} \mathrm{MnSO}_{4}, 2$ $\mu \mathrm{M} \mathrm{ZnSO}{ }_{4} \cdot \mathrm{H}_{2} \mathrm{O}, 0.5 \mu \mathrm{M} \mathrm{CuSO}_{4} \cdot \mathrm{H}_{2} \mathrm{O}, 0.5 \mu \mathrm{M} \mathrm{MoO}_{3}, 0.1$ $\mu \mathrm{M} \mathrm{NiSO}_{4}$. Both hydroponic solutions were buffered by the addition of $1 \mathrm{mM}$ MES, $\mathrm{pH} 5.5$. The assay ended at the $14^{\text {th }}$ day of hydroponic growth.

\section{Morphological and biochemical evaluations}

At the end of the experimental time period, five plants of each species and treatment were harvested and the length and fresh weight of shoots and roots was measured. Also, the number of secondary roots was counted and the chlorophyll concentration was quantified accordingly to Abadía et al. (1984).

Fe reduction was measured in the roots of five intact plants via the spectrophotometric measurement of $\mathrm{Fe}^{2+}$ chelated to BPDS, as described in Vasconcelos and Grusak (2006). Rates of reduction were determined using the molar extinction coefficient of $22.14 \mathrm{mM}^{-1} \mathrm{~cm}^{-1}$. Roots and shoots were dried at $70{ }^{\circ} \mathrm{C}$ and $200 \mathrm{mg}$ of each sample was analyzed for the determination of Fe content using the ICP-OES Optima 7000 DV (PerkinElmer, Massachusetss, USA) with radial configuration, according to Roriz et al. (2014).

\section{Gene expression analysis}

Additional five replicates of each species and treatments were pooled and the RNA from leaves and roots was extracted following manufacturer's instructions, using the Qiagen RNeasy Plant Mini Kit (USA, \#74904). cDNA was synthesized using First Strand cDNA Synthesis Kit (Fermentas).

Candidate genes were selected according to their established (FRO2-like, IRT1-like, NRAMP3-like, VIT1-like, YSL1-like, ferritin) or possible (GCN2like) role on Fe metabolism. In order to identify orthologs for these genes, known sequences from Arabidopsis were blasted, and the most homologous sequence $\left(\mathrm{E}_{\text {value }}<10^{-20}\right)$ was selected (Table 1$)$. Quantitative Real-Time PCR (qPCR) reactions were performed on a Chromo4 thermocycler (BioRad). Amplifications were carried out using 1.25 $\mu \mathrm{M}$ of the specific primers and mixed to $12.5 \mu \mathrm{L}$ of 2xPCR iQ SYBR Green Supermix (Bio-Rad) and $100 \mathrm{ng}$ of cDNA in a final volume of $25 \mu \mathrm{l}$. Three technical replicates were performed for each gene tested in qPCR reactions, as well as for controls. 
Table 1 - Gene accession numbers and forward and reverse primer sequences used in quantitative Real-Time PCR analysis

\begin{tabular}{|c|c|c|c|}
\hline Gene & Species & $\begin{array}{c}\text { Accession } \\
\text { numbers }\end{array}$ & Primer sequences \\
\hline 18S rRNA & - & $\mathrm{X} 75080.1$ & $\begin{array}{l}\text { F 5'- TTAGGCCATGGAGGTTTGAG -3' } \\
\text { R 5'- GAGTTGATGACACGCGCTTA -3' }\end{array}$ \\
\hline \multirow{2}{*}{ FRO2-like } & G. $\max$ & XM_003548612.1 & $\begin{array}{l}\text { F 5'- TGCTTGGACTCACACCAGAG -3' } \\
\text { R 5' - AGAGGTAGAAACCGGGGAGA -3' }\end{array}$ \\
\hline & M. truncatula & XM_003622457.1 & $\begin{array}{l}\text { F 5'- CACTTGTGATGGTGAGTGGA -3' } \\
\text { R 5'- GATGGTGTGCCAGAAATAGG -3' }\end{array}$ \\
\hline \multirow{2}{*}{ IRT1-like } & G. $\max$ & XM_003520096.2 & $\begin{array}{l}\text { F 5'- GATTGCACCTGTGACACAAA -3' } \\
\text { R 5'- CAGCAAAGGCCTTAACCATA -3' }\end{array}$ \\
\hline & M. truncatula & XM_003630873.1 & $\begin{array}{l}\text { F 5'- GACAAAGGAACCGGAACAAA -3' } \\
\text { R 5'- TTGATGGAAGCAAAGTGCAG -3' }\end{array}$ \\
\hline \multirow{2}{*}{ YSL1-like } & G. $\max$ & XM_003536126.2 & $\begin{array}{l}\text { F 5'- GCTTTTGGAGCAGGTCTCAC -3' } \\
\text { R 5'- AGACCACAACCCACAAGTCC -3' }\end{array}$ \\
\hline & M. truncatula & XM_003602267.1 & $\begin{array}{l}\text { F 5'- GATCTTGGCCCACAACAAGT -3' } \\
\text { R 5'- ACTGCAGGAACCATCAAACC -3' }\end{array}$ \\
\hline \multirow{2}{*}{ VIT1-like } & G. $\max$ & XM_003525172.2 & $\begin{array}{l}\text { F 5'- TTGTTAGCTTGGCGTGACAG -3' } \\
\text { R 5'- TGCAACCAAGGTAACCACAA -3' }\end{array}$ \\
\hline & M. truncatula & XM_003630932.1 & $\begin{array}{l}\text { F 5'- GGGTGGAATTGTTCCTCTCA -3' } \\
\text { R 5'- AGCACTCCTGATTGGCTTGT -3' }\end{array}$ \\
\hline \multirow{2}{*}{ ferritin } & G. $\max$ & U31648.1 & $\begin{array}{l}\text { F 5'- CCCCTTATGCCTCTTTCCTC -3' } \\
\text { R 5'- GCTTTTCAGCGTGCTCTCTT -3' }\end{array}$ \\
\hline & M. truncatula & XM_00362331.1 & $\begin{array}{l}\text { F 5'- GTAAGAAATGGGGTGGTGGA -3' } \\
\text { R 5'- CGAGCCAAAGAAACTTGAGG -3, }\end{array}$ \\
\hline \multirow{2}{*}{ NRAMP3-like } & G. $\max$ & XM_003524624.2 & $\begin{array}{l}\text { F 5'- TGTTCAGTCAAGGCAGGTTG -3' } \\
\text { R 5'- CCAGCATTTACAAGGCCAAT -3' }\end{array}$ \\
\hline & M. truncatula & XM_003611600.1 & $\begin{array}{l}\text { F 5'- TTTGGATCCTGGAAACTTGG -3' } \\
\text { R 5'- GCTGAATCAAAAGCCCCATA -3' }\end{array}$ \\
\hline \multirow{2}{*}{ GCN2-like } & G. $\max$ & XM_006592086.1 & $\begin{array}{l}\text { F 5'- ATCCTTGCCTCATCACCAAC -3' } \\
\text { R 5'- ATGGGGAACTGTGTTTGAGC -3' }\end{array}$ \\
\hline & M. truncatula & XM_003636896.1 & $\begin{array}{l}\text { F 5'- GTAACCGAGGTCCGAGATGA -3' } \\
\text { R 5'- CTCCACCATGGGTCAGAAGT -3' }\end{array}$ \\
\hline
\end{tabular}

The amplification of all genes was performed accordingly to Han et al. (2013). The comparative CT method $(\triangle \Delta C T)$ (Livak and Schmittgen, 2001) was utilized for the relative quantification of gene expression value of Fe stress related genes using the 18S rRNA gene as the housekeeping gene (Opticon Monitor 3 Software, Bio-Rad).

\section{RESULTS AND DISCUSSION}

For several organisms, Fe represents a cofactor in vital metabolic pathways such as the electron transport chain of respiration. Plants have an additional need for $\mathrm{Fe}$ because photosynthesis and chlorophyll biosynthesis both require this micronutrient (Jeong and Guerinot, 2009). Thus, how plants maintain $\mathrm{Fe}$ homeostasis and the anatomical modifications concerning Fe absence is a biologically relevant question. In the current work, when Fe was absent, both G. max and M. truncatula behaved similarly, developing characteristic IDC symptoms, such as impaired growth, observed by the reduction in plant weight and length (Table 2). More specifically, G. max had 2.2- and 2.1-fold lower fresh weight in shoots and roots, respectively, under Fe deficiency, which was more pronounced than $M$. truncatula, that had a reduction of 1.5- and 1.8-fold (Table 2).

Another important characteristic associated with the absence of $\mathrm{Fe}$ is the development of secondary structures. Here, plants submitted to -Fe conditions showed swelling of root tips and increased number of secondary structures, namely, an average of $60 \%$ more for G. max and 69 $\%$ more for M. truncatula (Table 2). The increased number of secondary structures helps the plant in augmenting the absorbable area for Fe uptake, and the scavenging of Fe in the rhizosphere (Schmidt, 
Table 2 - Fresh weight (FW) (g), length (cm) and number (\#) of secondary roots of G. max and M. truncatula grown hydroponically in Fe-sufficient $(\mathrm{Fe}+)$ and Fe-deficient (Fe-) conditions. Data are means $\pm \mathrm{SE}$ of five independent replicates. For each parameter analyzed, different letters represent significant differences between samples $(p<0.05)$

\begin{tabular}{cccccc}
\hline & & \multicolumn{2}{c}{ G. $\boldsymbol{m a x}$} & \multicolumn{2}{c}{ M. truncatula } \\
\cline { 2 - 6 } & & Fe+ & Fe- & Fe+ & Fe- \\
\hline \multirow{2}{*}{ Shoot } & FW & $6.44 \pm 0.53 \mathrm{a}$ & $2.92 \pm 0.32 \mathrm{~b}$ & $0.82 \pm 0.09 \mathrm{c}$ & $0.55 \pm 0.07 \mathrm{~d}$ \\
\cline { 2 - 6 } & Length & $30.5 \pm 0.70 \mathrm{a}$ & $16.92 \pm 0.65 \mathrm{~b}$ & $10.75 \pm 0.49 \mathrm{c}$ & $7.33 \pm 0.50 \mathrm{~d}$ \\
\hline \multirow{2}{*}{ Root } & FW & $5.38 \pm 0.46 \mathrm{a}$ & $2.61 \pm 0.24 \mathrm{~b}$ & $1.03 \pm 0.11 \mathrm{c}$ & $0.57 \pm 0.09 \mathrm{~d}$ \\
\cline { 2 - 6 } & Length & $49.75 \pm 1.16 \mathrm{a}$ & $27.08 \pm 0.78 \mathrm{~b}$ & $35.42 \pm 1.51 \mathrm{c}$ & $28.75 \pm 1.84 \mathrm{~d}$ \\
\hline \# Secondary Roots & & $34.2 \pm 3.09 \mathrm{a}$ & $57.00 \pm 5.14 \mathrm{~b}$ & $17.4 \pm 1.62 \mathrm{c}$ & $25.2 \pm 2.95 \mathrm{~d}$ \\
\hline
\end{tabular}

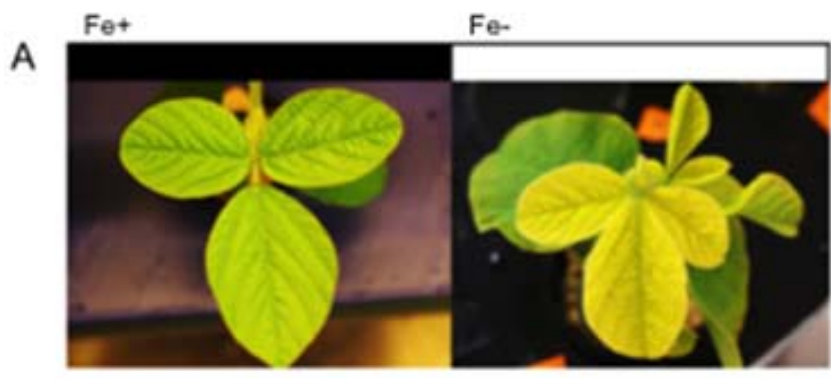

Glycine max

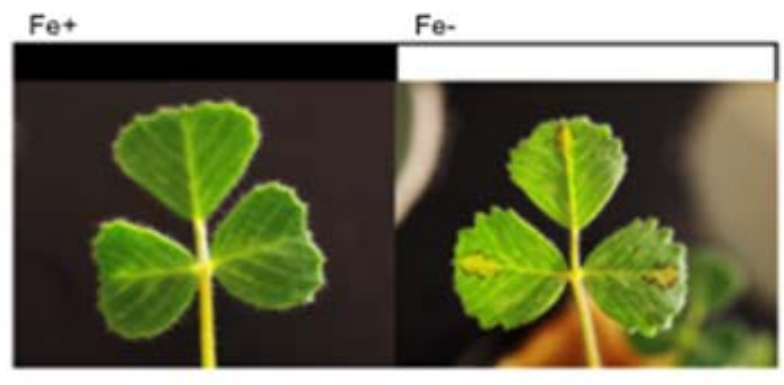

Medicago truncatula

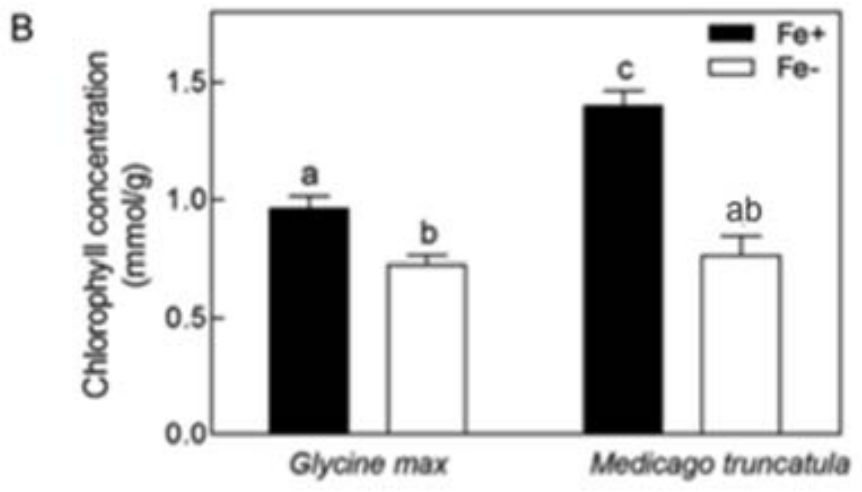

Figure 1 - Visible chlorosis symptoms (A) and chlorophyll concentration (B) of G. max and M. truncatula plants grown hydroponically in Fe-sufficient $(\mathrm{Fe}+)$ and Fe-deficient (Fe-) conditions. Data are means $+\mathrm{SE}$ of five independent replicates. Different letters represent significant differences between samples $(P<0.05)$.

1999). Since the surface of root hairs can represent up to $70 \%$ of the total root surface area (LópezBucio et al., 2003), the relevance of root hairs in nutrient uptake is crucial.

At the shoot level, the absence of Fe is known to inhibit chloroplast biogenesis and chlorophyll biosynthesis, leading to the development of chlorosis, especially in younger leaves (Henriques et al., 2002). Also, Fe starved plants may be more prone to oxidative damage (Kumar et al., 2010), leading to the accumulation of ROS, to oxidative stress, and to lower chlorophyll levels and increased chlorosis symptoms (as seen in Figure 1).

In this work, chlorosis symptoms appear to be more severe in G. max plants when compared to M. truncatula plants (Figure 1A), but the absolute values of chlorophyll concentration in Figure 1B seem to be contradictory. However, this is due to the fact that G. max plants, even under Fe sufficiency, weren't as green as $M$. truncatula plants under the 


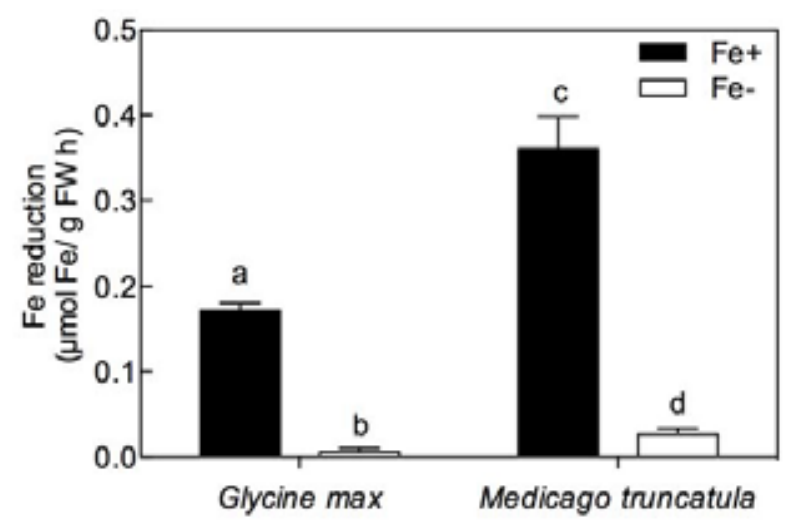

Figure 2-Root Fe reductase activity of G. $\max$ and $M$. truncatula plants grown hydroponically in Fesufficient $(\mathrm{Fe}+)$ and Fe-deficient (Fe-) conditions. Data are means + SE of five independent replicates. Different letters represent significant differences between samples $(P<0.05)$.
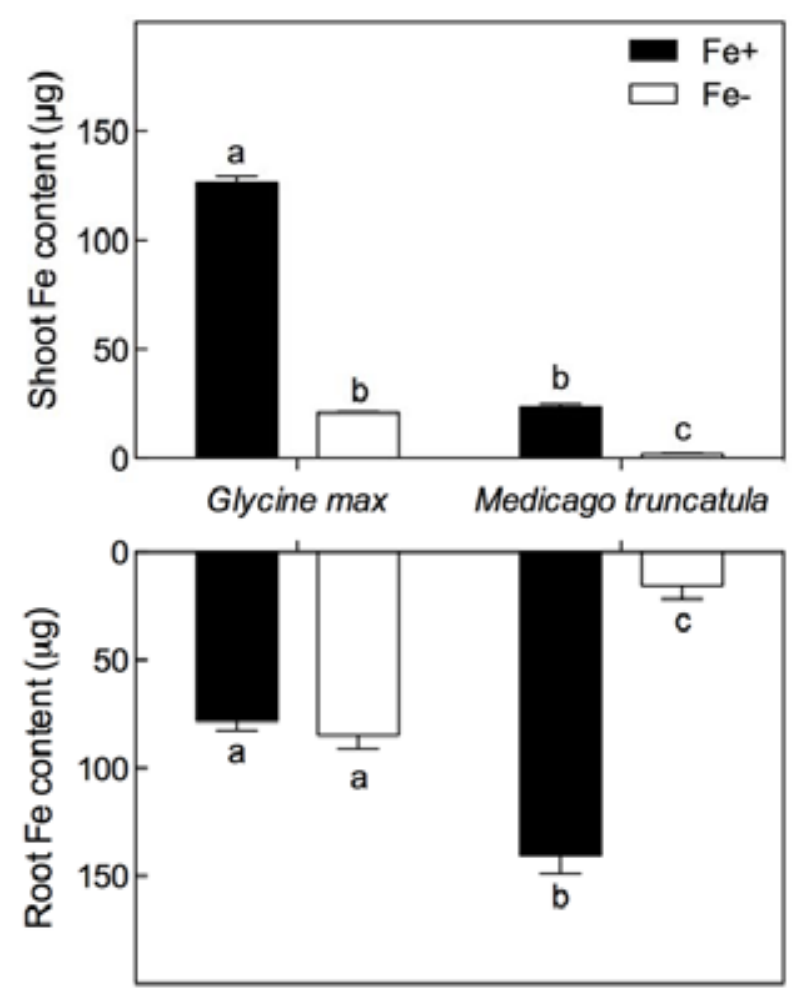

Figure 3 - Fe content of shoots and roots of G. max and $M$. truncatula grown hydroponically in Fe-sufficient $(\mathrm{Fe}+)$ and Fe-deficient (Fe-) conditions. Data are means $+S E$ of five independent replicates. Different letters represent significant differences between samples $(P<0.05)$.

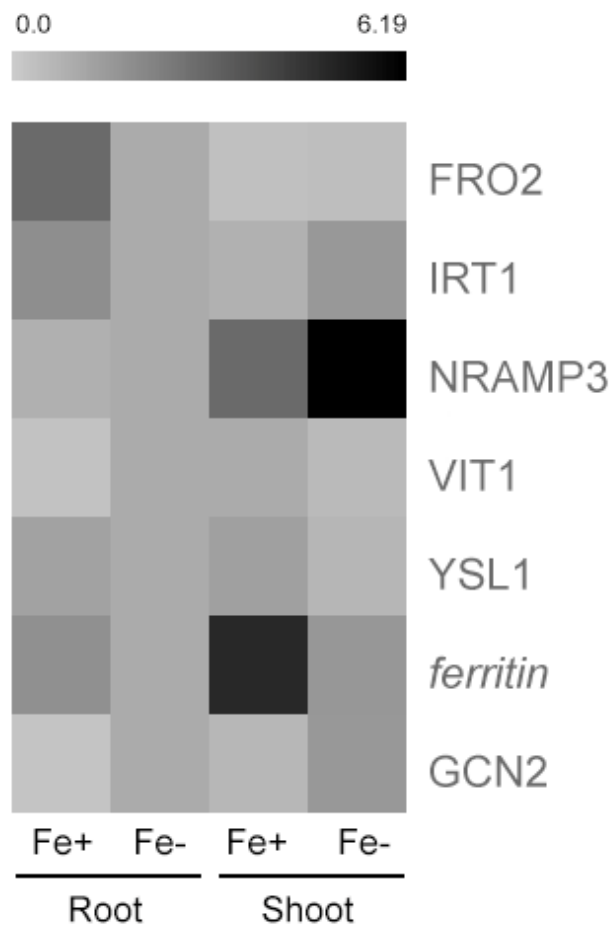

Figure 4 - HeatMap of the expression patterns of FR02-, IRT1, NRAMP3-, VIT1- and YSL1-like genes and ferritin and GCN2-like genes in root and shoot tissues of G. max plants grown hydroponically in Fesufficient $(\mathrm{Fe}+)$ and Fe-deficient (Fe-) conditions. "Fe- Root" was the reference sample; expression was normalized with $18 \mathrm{~S}$ rRNA housekeeping gene. In black: increased gene expression; in light grey: lower gene expression. Total RNA was extracted from a pool of five independent replicates. Corresponding values are presented in Table 3.

Table 3 - Fe deficiency-related genes relative expression values of $G$. max plants grown under Fe-sufficient $(\mathrm{Fe}+)$ and Fe-deficient (Fe-) hydroponic conditions. Total RNA was extracted from a pool of five independent replicates

\begin{tabular}{c|cc|cc}
\cline { 2 - 5 } & \multicolumn{2}{c|}{ Root } & \multicolumn{2}{c}{ Shoot } \\
\cline { 2 - 5 } & Fe+ & Fe- & Fe+ & Fe- \\
\hline FRO2-like & 2.98 & 1 & 0.37 & 0.41 \\
IRT1-like & 1.87 & 1 & 0.81 & 1.60 \\
NRAMP3-like & 0.84 & 1 & 2.98 & 6.19 \\
VIT1-like & 0.28 & 1 & 0.98 & 0.55 \\
YSL1-like & 1.28 & 1 & 1.32 & 0.68 \\
ferritin & 1.81 & 1 & 4.95 & 1.62 \\
GCN2-like & 0.23 & 1 & 0.64 & 1.57 \\
\hline
\end{tabular}


same treatment, leading to an acuter decrease in chlorophyll concentration.

Root Fe uptake capacity is linked with the solubilisation of Fe in the rhizosphere by the plant's root Fe reductase activity, which is necessary to convert the less soluble $\mathrm{Fe}^{3+}$ to the more soluble $\mathrm{Fe}^{2+}$ (García et al., 2013). Here, for both species, the enzyme was more active in $\mathrm{Fe}+$ conditions and was higher in M. truncatula plants (Figure 2). It has been hypothesized that, for some genotypes, Fe is necessary for the functioning of the reductase enzyme itself (Blair et al., 2010). Although most studies imply that Fe reduction is induced under Fe deficiency (Wang et al., 2013; Zha et al., 2014), it has already been described that this is not always this way (Vasconcelos and Grusak., 2006; Santos et al., 2015).

In order to understand how Fe deficiency affects the mineral composition of Fe in G. $\max$ and $M$. truncatula, root and shoot tissues were analyzed by ICP-OES. When G. max was faced with the lack of $\mathrm{Fe}$, it appeared to accumulate its internal Fe storage in the roots and the shoot Fe content decreased six-fold (Figure 3). It has been seen before that in response to shortage in mineral nutrition plants usually allocate more resources to the roots (Hermans et al., 2006; Santos et al., 2015). On the other hand, M. truncatula plants had a general reduction in $\mathrm{Fe}$ content in both tissues under $\mathrm{Fe}$ deficiency.

To further understand the mechanisms triggered by Fe shortage, it is crucial to comprehend the key conserved molecular players involved in nutrient uptake (e.g. FRO2 and IRT1), transport (e.g. NRAMP3, VIT1 and YSL1) and storage (e.g. ferritin), as well as identify novel candidate genes, that could have important roles in Fe metabolism (GCN2). When plants are faced with stress situations, the rate of nutrient uptake needs to increase, in order to compensate the lack of Fe. Thus, root Fe uptake related genes FRO2 and IRT1 are extremely important since they participate in this critical step concerning the plant response to Fe deficiency, and which control the efficiency of Fe uptake.

The results obtained for G. max plants show that in $\mathrm{Fe}$ - the expression of FRO2-like was decreased by three-fold (Figure 4), accordingly to the $\mathrm{Fe}$ reductase activity previously described (Figure 2). On the contrary, M. truncatula roots overexpressed FRO2-like gene under Fe deficiency (Figure 5), as previously obtained in A. thaliana (Robinson et al., 1999), tomato (Li et al., 2004) and soybean (Santos et al., 2016). When Fe was present in sufficient amounts, $M$. truncatula had almost null FRO2-like expression (Figure 5); since from the beginning of the trial, plants were in optimal conditions, they captured sufficient $\mathrm{Fe}$ to meet their daily requirements, thus inhibiting FRO2-like expression in order to avoid Fe toxicity. However, the Fe reductase activity was higher under $\mathrm{Fe}+$ conditions (like in G. max). The Fe reduction is thought to be the rate-limiting step for Fe transport since Fe transporters, such as IRT1, do not reach saturation at normally achieved concentrations of $\mathrm{Fe}^{2+}$ (Grusak et al., 1990). If there is no Fe being reduced, IRT1-like should consequently present lower activity, which was clearly observed in G. $\max$ Fe- roots (Figure 4). In both species, the levels of IRT1-like expression were very similar to those obtained for FRO2-like (Figures 4 and 5), suggesting that IRT1-like is co-regulated with this gene, as previously seen in Arabidopsis thaliana (Vert, 2002; Kim and Guerinot, 2007).

After Fe is transported into the roots by IRT1, the transport of this nutrient across the plant is another crucial step that needs to be well known to efficiently develop an IDC mitigation or a biofortification strategy. Fe transporter families, such as VIT, NRAMP and YSL, are extremely important in Fe metabolism, as they assure that Fe is efficiently delivered to shoots, and other plant edible parts and storage organs. NRAMP3 and VIT1 have contrasting functions: while the first is responsible for the remobilization from the vacuole (Lanquar et al., 2005), the second is responsible for the Fe loading in the vacuole (Kim et al., 2006). Studies in A. thaliana demonstrate that NRAMP3 is an $\mathrm{H}^{+}$metal symporter responsible for $\mathrm{Fe}$ and Mn remobilization from the vacuole, a crucial step during early seedling development (Lanquar et al., 2010). Accordingly, under Fe deficiency, as plants need more remobilization of Fe to respond to their needs, NRAMP3-like was more expressed (Figures 4 and 5) and VIT1-like was repressed, because plants activate VIT1-like in Fe sufficient conditions to increase $\mathrm{Fe}^{2+}$ uptake into the vacuole for storage 


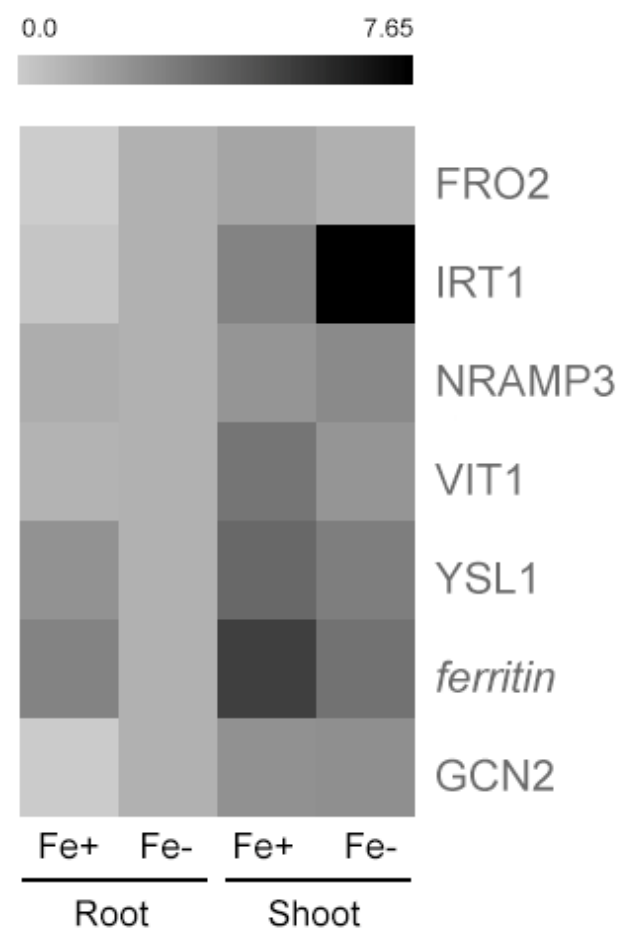

Figure 5 - HeatMap of the expression patterns of FRO2-, IRT1, NRAMP3-, VIT1- and YSL1-like genes and ferritin and GCN2-like genes in root and shoot tissues of M. truncatula plants grown hydroponically in Fesufficient $(\mathrm{Fe}+)$ and Fe-deficient (Fe-) conditions. "Fe- Root" was the reference sample; expression was normalized with 18S rRNA housekeeping gene. In light grey: lower gene expression; in black: increased gene expression. Total RNA was extracted from a pool of five independent replicates. Corresponding values are presented in Table 4.

purposes (Brear et al., 2013). Studies in A. thaliana (Kim and Guerinot, 2007) demonstrated that AtNRAMP3 and AtVIT1 mutants present arrested seedling growth when grown on Fe deficient soils. Moreover, Zhang et al. (2012) reported that the disruption of the rice VIT orthologues (OsVIT1 and OsVIT2) increased Fe and $\mathrm{Zn}$ accumulation in rice seeds and decreased $\mathrm{Fe}$ and $\mathrm{Zn}$ in the leaves.

As well as NRAMP3-like and VIT1-like, the YSL1like transporter may also play a crucial role in the control of the amount of Fe translocated to the seeds of G. max and M. truncatula. Both species had similar expression patterns (Figures 4 and 5), where both tissues presented higher levels in $\mathrm{Fe}+$ conditions, suggesting a role in Fe translocation at diverse plant organs, as seen before (Kim et al., 2006). This gene is involved in the transport of
Table 4-Fe deficiency-related genes relative expression values of $M$. truncatula plants grown under Fesufficient $(\mathrm{Fe}+)$ and Fe-deficient (Fe-) hydroponic conditions. Total RNA was extracted from a pool of five independent replicates

\begin{tabular}{c|cc|cc}
\cline { 2 - 5 } & \multicolumn{2}{|c|}{ Root } & \multicolumn{2}{c}{ Shoot } \\
\cline { 2 - 5 } & Fe+ & Fe- & Fe+ & Fe- \\
\hline FRO2-like & 0.01 & 1 & 1.45 & 1.05 \\
IRT1-like & 0.25 & 1 & 2.75 & 7.65 \\
NRAMP3-like & 1.15 & 1 & 2.10 & 2.46 \\
VIT1-like & 0.94 & 1 & 3.28 & 2.10 \\
YSL1-like & 2.17 & 1 & 3.77 & 2.91 \\
ferritin & 2.73 & 1 & 5.25 & 3.37 \\
GCN2-like & 0.05 & 1 & 2.19 & 2.31 \\
\hline
\end{tabular}

the $\mathrm{Fe}^{2+}$-NA complexes (Kim et al., 2006) that are hypothesized as the main transportable Fe form in the phloem (Jean et al., 2005; Waters et al., 2006; Chu et al., 2010). Jean et al. (2005) used A. thaliana lines with a knock out mutation in AtYSL1, and the levels of NA and Fe in leaves and seeds decreased, as well as germination rates, even when plants were grown in Fe excess, showing that Fe and NA levels in seeds rely in part on YSL1 function.

Storage proteins such as ferritin play an important role in Fe homeostasis, assuring that Fe in excess is in a bio-available way in case of cellular needs but yet nonreactive with oxygen (Briat et al., 2010). Thus, the higher expression levels of this gene in Fe sufficient soybean and barrel medic plants are understandable (Figures 4 and 5) and are coherent with previous studies (Santos et al., 2016). This protein manages the insolubility and potential toxicity of $\mathrm{Fe}$ in the presence of oxygen, being involved in oxidative protection by sequestering free Fe (Lobreaux et al., 1995).

Even though several gene families are known to be involved in the Fe uptake mechanism, transport and storage, there are still many undiscovered genes that may have important roles in these processes. Therefore, it is worthwhile to find candidate genes that could have an important role in Fe metabolism. To this end, a novel gene was studied in the current 
work: GCN2-like. Both G. $\max$ and M. truncatula plants over-expressed GCN2-like under $\mathrm{Fe}$ deficient conditions (Figures 4 and 5), particularly at the root level, and it seems to indicate a role for GCN2-like in alleviating Fe stress, for both legume species. Lageix et al. (2008) showed that AtGCN2 was strongly activated following wounding and exposure to key hormones, and suggested that this enzyme plays a role in plant defense responses to insect pathogens, representing a key player linking biotic and abiotic stresses. Moreover, no studies have looked at the possible role of GCN2 and Fe nutrition, which highlights the importance of the current work. Further studies to link its role on Fe metabolism are under way.

The current work compared the responses of two legume species, soybean and barrel medic, to $\mathrm{Fe}$ deficiency. Taken together, the results described above suggest a conservation of anatomical and biochemical responses in the two legume species.
Also, it is apparent that for genes such as FRO2-like and IRT1-like the regulation differs between these two legumes and is not conserved with other plants such as $A$. thaliana. It shows that generalizations in Fe uptake processes should not be lightly done. Finally, a novel sequence showing up-regulation under Fe deficiency was identified, opening doors to future studies looking at the role of this gene under Fe deficiency.

\section{ACKNOWLEDGMENTS}

The authors would like to thank Prof. C. Pinto Ricardo for providing the Medicago truncatula cultivar "Luzerna revilheira" seeds and Mariana Roriz for the ICP analysis. This work was supported by National Funds from FCT through projects PEst-OE/EQB/LA0016/2013 and PTDC/ AGRPRO/3972/2014, and PhD scholarship SFRH/ $\mathrm{BD} / 78353 / 2011$.

\section{REFERENCES}

Abadía, J.; Monge, E.; Montañes, L. and Heras, L. (1984) - Extraction of iron from plant leaves by Fe(II) chelators. Journal of Plant Nutrition, vol. 7, n. 1-5, p. 777-784. http://dx.doi.org/10.1080/01904168409363241

Andaluz, S.; Rodríguez-Celma, J.; Abadía, A.; Abadia, J. and López-Millán, A.F. (2009) - Time course induction of several key enzymes in Medicago truncatula roots in response to Fe deficiency. Plant Physiology, vol. 47, n. 11-12, p. 1082-1088. http://dx.doi.org/10.1016/j.plaphy.2009.07.009

Bell, C.J.; Dixon, R.A.; Farmer, A.D.; Flores, R.; Inman, J.; Gonzales, R.A.; Harrison, M.J.; Paiva, N.L.; Scott, A.D.; Weller, J.W.; and May, G.D. (2001) - The Medicago genome initiative: a model legume database. Nucleic Acids Research, vol. 29, n. 1, p. 114-117. http://dx.doi.org/10.1093/nar/29.1.114

Blair, M.W.; Knewtson, S.J.B.; Astudillo, C.; Li, C.; Fernandez, A.C. and Grusak, M.A. (2010) - Variation and inheritance of iron reductase activity in the roots of common bean (Phaseolus vulgaris L.) and association with seed iron accumulation QTL. BMC Plant Biology, vol. 10, p. 215-2010. http://dx.doi.org/10.1186/1471-2229-10-215

Bolon, Y.; Joseph, B.; Cannon, S.B.; Graham, M.A.; Diers, B.W.; Farmer, A.D.; May, G.D.; Muehlbauer, G.J.; Specht, J.E.; Tu, J.T.; Weeks, N.; Xu, W.W.; Shoemaker, R.C. and Vance, C.P. (2010) - Complementary genetic and genomic approaches help characterize the linkage group I seed protein QTL in soybean. BMC Plant Biology, vol. 10, art. 41. http://dx.doi.org/10.1186/1471-2229-10-41

Brear, E.M.; Day, D.A. and Smith, P.M.C. (2013) - Iron: an essential micronutrient for the legume-rhizobium symbiosis. Frontiers in Plant Science, vol. 4, art. 359. http://dx.doi.org/10.3389/fpls.2013.00359

Briat, J.F.; Ravet, K.; Arnaud, N.; Duc, C.; Boucherez, J.; Tourain, B.; Cellier, F. and Gaymard, F. (2010) - New insights into ferritin synthesis and function highlight a link between iron homeostasis and oxidative stress in plants. Annals of Botany, vol. 105, n. 5, p. 811-822. http://dx.doi.org/10.1093/aob/mcp128

Choi, H.; Mun, J.; Kim, D.; Zhu, H.; Baek, J.; Mudge, J.; Roe, B.; Ellis, N.; Doyle, J.; Kiss, G.B.; Young, N.D.; and Cook, D.R. (2004) - Estimating genome conservation between crop and model species. Proceedings of the National Academy of Science of the USA, vol. 101, n. 43, p. 15289-15294.

http://dx.doi.org/10.1073/pnas.0402251101 
Chu, H.H.; Chiecko, J.; Punshon, T.; Lanzirotti, A.; Lahner, B.; Salt, D.E. and Walker, E.L. (2010) - Successful reproduction requires the function of Arabidopsis Yellow Stripe-Like1 and Yellow Stripe-Like3 metalnicotianamine transporters in both vegetative and reproductive structures. Plant Physiology, vol. 154, n. 1, p. 197-210. http://dx.doi.org/10.1104/pp.110.159103

Dhingra, S. and Jood, S. (2001) - Organoleptic and nutritional evaluation of wheat breads supplemented with soybean and barley flour. Food Chemistry, vol. 77, n. 4, p. 479-488. http://dx.doi.org/10.1016/s0308-8146(01)00387-9

García, M.J.; Romera, F.J.; Stacey, M.G.; Stacey, G.; Villar, E.; Alcántara, E. and Pérez-Vicente, R. (2013) Shoot to root communication is necessary to control the expression of iron-acquisition genes in Strategy I plants. Planta, vol. 237, n. 1, p. 65-75. http://dx.doi.org/10.1007/s00425-012-1757-0

Grotz, N. and Guerinot, M.L. (2006) - Molecular aspects of Cu, Fe and Zn homeostasis in plants. Biochimica and Biophysica Acta, vol. 1763, n. 7, p. 595-608. http://dx.doi.org/10.1016/j.bbamcr.2006.05.014

Grusak, M.A. (1999) - Genomics-assisted plant improvement to benefit human nutrition and health. Trends in Plant Science, vol. 4, n. 5, p. 164-166. http://dx.doi.org/10.1016/S1360-1385(99)01400-4

Grusak, M.A.; Welch, R.M. and Kochian, L.V. (1990) - Does iron deficiency in Pisum sativum enhance the activity of the root plasmalemma iron transport protein? Plant Physiology, vol. 94, n. 3, p. 1353-1357. http://dx.doi.org/10.1104/pp.94.3.1353

Han, B.; Yang, Z.; Samma, M.K.; Wang, R. and Shen, W. (2013) - Systematic validation of candidate reference genes for qRT-PCR normalization under iron deficiency in Arabidopsis. Biometals, vol. 26, n. 3, p. 403-413. http://dx.doi.org/10.1007/s10534-013-9623-5

Henriques, R.; Jásik, J.; Klein, M.; Martinoia, E.; Feller, U.; Schell, J.; Pais, M.S. and Koncz, C. (2002) - Knock-out of Arabidopsis metal transporter gene IRT1 results in iron deficiency accompanied by cell differentiation defects. Plant Molecular Biology, vol. 50, n. 4, p. 587-597. http://dx.doi.org/10.1023/A:1019942200164

Hermans, C.; Hammond, J.P.; White, P.J. and Verbruggen, N. (2006) - How do plants respond to nutrient shortage by biomass allocation? Trends in Plant Science, vol. 11, n. 12, p. 610-617. http://dx.doi.org/10.1016/j.tplants.2006.10.007

Jean, M.L.; Schikora, A.; Mari, S.; Briat, J.F. and Curie, C. (2005) - A loss-of-function mutation in AtYSL1 reveals its role in iron and nicotianamine seed loading. The Plant Journal, vol. 44, n. 5, p. 769-782. http://dx.doi.org/10.1111/j.1365-313X.2005.02569.x

Jeong, J. and Guerinot, M.L. (2009) - Homing in on iron homeostasis in plants. Trends in Plant Science, vol. 14, n. 5, p. 280-285. http://dx.doi.org/10.1016/j.tplants.2009.02.006

Kim, S.A. and Guerinot, ML. (2007) - Mining iron: Iron uptake and transport in plants. FEBS Letters, vol. 581, n. 12, p. 2273-2280. http://dx.doi.org/10.1016/j.febslet.2007.04.043

Kim, S.A.; Punshon, T.; Lanzirotti, A.; Li, L.; Alonzo, J.M.; Ecker, J.R.; Kaplan, J. and Guerinot, M.L. (2006) - Localization of iron in Arabidopsis seed requires the vacuolar membrane transporter VIT1. Science, vol. 314, n. 5803, p. 1295-1298. http://dx.doi.org/10.1126/science.1132563

Krishnan, H.B. (2005) - Engineering soybean for enhanced sulfur amino acid content. Crop Science, vol. 45, n. 2, p. 454-461. http://dx.doi.org/10.2135/cropsci2005.0454

Kumar, P.; Tewari, R.K. and Sharma, P.N. (2010) - Sodium nitroprusside-mediated alleviation of iron deficiency and modulation of antioxidant responses in maize plants. AoB Plants, vol. 2010, art. plq002. http://dx.doi.org/10.1093/aobpla/plq002

Lageix, S.; Lanet, E.; Pouch-Pélissier, M.; Espagnol, M.; Robaglia, C.; Deragon, J. and Pélissier, T. (2008) Arabidopsis eIF2 $\alpha$ kinase GCN2 is essential for growth in stress conditions and is activated by wounding. BMC Plant Biology, vol. 8, art. 134. http://dx.doi.org/10.1186/1471-2229-8-134

Lanquar, V.; Lelievre, F.; Bolte, S.; Hames, C.; Alcon, C. and Neumann, D. (2005) - Mobilization of vacuolar iron by AtNRAMP3 and AtNRAMP4 is essential for seed germination on low iron. The EMBO Journal, vol. 24, n. 23, p. 4041-4051. http://dx.doi.org/10.1038/sj.emboj.7600864

Lanquar, V.; Ramos, M.S.; Lelievre, F.; Barbier-Brygoo, H.; Krieger-Liszkay, A. and Kramer, U. (2010) - Export of vacuolar manganese by AtNRAMP3 and AtNRAMP4 is required for optimal photosynthesis and growth under manganese deficiency. Plant Physiology, vol. 152, n. 4, p. 1986-1999. http://dx.doi.org/10.1104/pp.109.150946

Li, L.; Cheng, X. and Ling, H.Q. (2004) - Isolation and characterization of Fe(III)-chelate reductase gene LeFRO1 in tomato. Plant Molecular Biology, vol. 54, n. 1, p. 125-136. http://dx.doi.org/10.1023/B:PLAN.0000028774.82782.16 
Liao, X.; Lv, C.; Zhang, X.; Masuda, T.; Li, M. and Zhao, G. (2012) - A novel strategy of natural plant ferritin to protect DNA from oxidative damage during iron oxidation. Free Radicals Biology and Medicine, vol. 53, n. 2, p. 375-382. http://dx.doi.org/10.1016/j.freeradbiomed.2012.05.003

Libault, M.; Farmer, A.; Joshi, T.; Takahashi, K.; Langley, R.J.; Franklin, L.D.; He, J.; Xu, D.; May, G. and Stacey, G. (2010) - An integrated transcriptome atlas of the crop model Glycine max, and its use in comparative analyses in plants. The Plant Journal, vol. 63, n. 1, p. 86-99. http://dx.doi.org/10.1111/j.1365-313X.2010.04222.x

Liu, X.; Merchant, A.; Rockett, K.S.; McCormack, M. and Pajerowska-Mukhtar, K.M. (2015) - Characterization of Arabidopsis thaliana GCN2 kinase roles in seed germination and plant development. Plant Signaling and Behavior, vol. 10, n. 4, e992264. http://dx.doi.org/10.4161/15592324.2014.992264

Livak, K.J. and Schmittgen, T.D. (2001) - Analysis of relative gene expression data using real-time quantitative PCR and the 2- $\Delta \Delta C$ t method. Methods, vol. 25, n. 4, p. 402-408. http://dx.doi.org/10.1006/meth.2001.1262

Lobreaux, S.; Thoiron, S. and Briat, J.F. (1995) - Induction of ferritin synthesis in maize leaves by an iron-mediated oxidative stress. The Plant Journal, vol. 8, n. 3, p. 443-449. http://dx.doi.org/10.1046/j.1365-313X.1995.08030443.x

López-Bucio, J.; Cruz-Ramírez, A. and Herrera-Estrella, L. (2003) - The role of nutrient availability in regulating root architecture. Current Opinion in Plant Biology, vol. 6, n. 3, p. 280-287.

http://dx.doi.org/10.1016/S1369-5266(03)00035-9

Prasad, P.V.V. (2003) - Plant Nutrition: Iron Chlorosis. In: Thomas, B.; Murphy, D.J. and Murray, B.G. (Eds.) - Encyclopedia of Applied Plant Sciences. Elsevier, London, United Kingdom, p. 649-656.

Robinson, N.J.; Proctor, C.M.; Connolly, E.L. and Guerinot, M.L. (1999) - A ferric chelate reductase for iron uptake from soils. Nature, vol. 397, p. 694-697. http://dx.doi.org/10.1038/17800

Roriz, M.; Carvalho, S.M.P. and Vasconcelos, M.W. (2014) - High relative air humidity influences mineral accumulation and growth in iron deficient soybean plants. Frontiers in Plant Science, vol. 5, art. 726. http://dx.doi.org/10.3389/fpls.2014.00726

Santos, C.S.; Silva, A.I.; Serrão, I.; Carvalho, A.L. and Vasconcelos, M.W. (2013) - Transcriptomic analysis of iron deficiency related genes in the legumes. Food Research International, vol. 54, n. 1, p. 1162-1171. http://dx.doi.org/10.1016/j.foodres.2013.06.024

Santos, C.S.; Roriz, M.; Carvalho, S.M.P. and Vasconcelos, M.W. (2015) - Iron partitioning at an early growth stage impacts iron deficiency responses in soybean plants (Glycine max L.). Frontiers in Plant Science, vol. 6, art. 325. http://dx.doi.org/10.3389/fpls.2015.00325

Santos, C.S.; Carvalho, S.M.P.; Leite, A.; Moniz, T.; Roriz, M.; Rangel, A.O.S.S.; Rangel, M. and Vasconcelos, M.W. (2016) - Effect of tris(3-hydroxy-4-pyridinonate) iron(III) complexes on iron uptake and storage in soybean (Glycine max L.). Plant Physiology and Biochemistry, vol. 106, p. 91-100. http://dx.doi.org/10.1016/j.plaphy.2016.04.050

Schmidt, W. (1999) - Mechanisms and regulation of reduction-based iron uptake in plants. New Phytologist, vol. 141, n. 1, p. 1-26. http://dx.doi.org/10.1046/j.1469-8137.1999.00331.x

Schmutz, J.; Cannon, S.; Schlueter, J.; Ma, J.; Hyten, D.; Song, Q.; Mitros, T.; Nelson, W.; Hyten, D.L.; Song, Q.; Thelen, J.J.; Cheng, J.; Xu, D.; Hellsten, U.; May, G.D.; Yu, Y.; Sakurai, T.; Umezawa, T.; Bhattacharyya, M.K.; Sandhu, D.; Valliyodan, B., Lindquist, E.; Peto, M.; Grant, D.; Shu, S.; Goodstein, D.; Barry, K.; Futrell-Griggs, M.; Abernathy, B.; Du, J.; Tian, Z.; Zhu, L.; Gill, N.; Joshi, T.; Libault, M.; Sethuraman, A.; Zhang, X.-C.; Shinozaki, K.; Nguyen, H.T.; Wing, R.A.; Cregan, P. Specht, J.; Grimwood, J.; Rokhsar, D.; Stacey, G.; Shoemaker, R.C. and Jackson, S.A. (2010) - Genome sequence of the palaeopolyploid soybean (Glycine max (L.) Merr.). Nature, vol. 463, p. 178-183. http://dx.doi.org/10.1038/nature08670

Trieu, A.T.; Burleigh, S.H.; Kardailsky, I.V.; Maldonado-Mendoza, I.E.; Versaw, W.K.; Blaylock, L.A.; Shin, H.; Chiou, T.-J.; Katagi, H.; Dewbre, G.R.; Weigel, D. and Harrison, M.J. (2000) - Transformation of Medicago truncatula via infiltration of seedlings or flowering plants with Agrobacterium. The Plant Journal, vol. 22, $\mathrm{n}$. 6, p. 531-542. http://dx.doi.org/10.1046/j.1365-313x.2000.00757.x

Vasconcelos, M. and Grusak, M.A. (2006) - Status and future developments involving plant iron in animal and human nutrition. In: Barton, L.L. and Abadía, J. (Eds.) - Iron nutrition in plants and rhizospheric micoorganisms. Springer-Life Sciences, New York, USA, p. 1-22.

Vasconcelos, M.W. and Grusak, M.A. (2013) - Morpho-physiological parameters affecting iron deficiency chlorosis in soybean (Glycine max L.). Plant and Soil, vol. 374, p. 161-172. http://dx.doi.org/10.1007/s11104-013-1842-6 
Vert, G. (2002) - IRT1, an Arabidopsis transporter essential for iron uptake from the soil and for plant growth. Plant Cell, vol. 14, n. 6, p. 1223-1233. http://dx.doi.org/10.1105/tpc.001388

Wang, N.; Cui, Y.; Liu, Y.; Fan, H.; Du, J.; Huang, Z.; Yuan, Y.; Wu, H. and Ling, H.Q. (2013) - Requirement and functional redundancy of $\mathrm{Ib}$ subgroup bHLH proteins for iron deficiency responses and uptake in Arabidopsis thaliana. Molecular Plant, vol. 6, n. 2, p. 503-513. http://dx.doi.org/10.1093/mp/sss089

Waters, B.M.; Blevins, D.G. and Eide, D.J. (2002) - Characterization of FRO1, a Pea Ferric-Chelate Reductase Involved in Root Iron Acquisition. Plant Physiology, vol. 129, n. 1, p. 85-94. http://dx.doi.org/10.1104/pp.010829

Waters, B.M.; Chu, H.H.; Didonato, R.J.; Roberts, L.A.; Eisley, R.B.; Lahner, B.; Salt, D.E. and Walker, E.L. (2006) - Mutations in Arabidopsis yellow stripe-like1 and yellow stripe-like3 reveal their roles in metal ion homeostasis and loading of metal ions in seeds. Plant Physiology, vol. 141, n. 4, p. 1446-1458. http://dx.doi.org/10.1104/pp.106.082586

White, P.J. and Broadley, M.R. (2005) - Biofortifying crops with essential mineral elements. Trends in Plant Science, vol. 10, n. 12, p. 586-593. http://dx.doi.org/10.1016/j.tplants.2005.10.001

Yan, H.H.; Mudge, J.; Kim, D.J.; Shoemaker, R.C.; Cook, D.R. and Young, N.D. (2004) - Comparative physical mapping reveals features of microsynteny between Glycine max, Medicago truncatula, and Arabidopsis thaliana. Genome, vol. 47, n. 1, p. 141-155. http://dx.doi.org/10.1139/g03-106

Zha, Q.; Wang, Y.; Zhang, X.Z. and Han, Z.H. (2014) - Both immanently high active iron contents and increased root ferrous uptake in response to low iron stress contribute to the iron deficiency tolerance in Malus xiaojinensis. Plant Science, vol. 214, p. 47-56. http://dx.doi.org/10.1016/j.plantsci.2013.10.002

Zhang, Y.; Wang, Y.; Kanyuka. K.; Parry, M.A.; Powers, S.J. and Halford, N.G. (2008) - GCN2-dependent phosphorylation of eukaryotic translation initiation factor-2alpha in Arabidopsis. Journal of Experimental Botany, vol. 59, n. 11, p. 3131-3141. http://dx.doi.org/10.1093/jxb/ern169

Zhang, Y.; Xu, Y.H.; Yi, H.Y. and Gong, J.M. (2012) - Vacuolar membrane transporters OsVIT1 and OsVIT2 modulate iron translocation between flag leaves and seeds in rice. The Plant Journal, vol. 72, n. 3, p. 400410. http://dx.doi.org/10.1111/j.1365-313X.2012.05088.x 